九州大学学術情報リポジトリ

Kyushu University Institutional Repository

\title{
Molecular Diagnosis of the Biological Control Agent Nesidiocoris tenuis (Tobacco Plant Bug) and Its Allied Species (Insecta: Hemiptera) Using COI Barcoding
}

Kim, Junggon

Department of Applied Biology, College of Agriculture and Life Sciences, Chungnam National University

Lee, Hodan

Department of Applied Biology, College of Agriculture and Life Sciences, Chungnam National University

Lee, Wang Hee

Department of Biosystems Machinery Engineering, College of Agriculture and Life Sciences, Chungnam National University

Yu, Yong Man

Department of Applied Biology, College of Agriculture and Life Sciences, Chungnam National University

他

https://doi.org/10.5109/1685885

出版情報: 九州大学大学院農学研究院紀要. 61 (2)，pp.293-297，2016-09-01. Faculty of Agriculture, Kyushu University

バージョン :

権利関係 : 


\title{
Molecular Diagnosis of the Biological Control Agent Nesidiocoris tenuis (Tobacco Plant Bug) and Its Allied Species (Insecta: Hemiptera) Using COI Barcoding
}

\author{
Junggon KIM ${ }^{1}$, Hodan LEE ${ }^{1}$, Wang Hee $\mathrm{LEE}^{2 *}$, Yong Man YU', \\ Chisa YASUNAGA-AOKI and Sunghoon JUNG ${ }^{1 *}$ \\ Laboratory of Insect Pathology and Microbial Control, Institute of Biological Control, \\ Faculty of Agriculture, Kyushu University, Fukuoka 812-8581, Japan \\ (Received April 28, 2016 and accepted May 10, 2016)
}

\begin{abstract}
DNA barcoding is a useful molecular method for identification of certain animal groups. It uses partial DNA sequences of mitochondrial genes such as the cytochrome c oxidase subunit I (COI) gene. In this study, effectiveness of the COI barcoding as an identification tool for Nesidiocoris tenuis, which is used as a biological control agent, and for its allied species, was evaluated. All the species used in this study had a distinct COI barcode sequence, and the Neighbor-Joining (NJ) tree based on COI sequences almost matched the morphological classification for most genera investigated in this study, except for the genus Cyrtopeltis. The average interspecific genetic distance between $N$. tenuis and its allied species was 111 times higher than the average intraspecific genetic distance. The tree showed shallow intraspecific divergences and deep interspecific divergences. Therefore, our results suggested that COI barcode for $N$. tenuis and its allied species can be used as an effective identification tool by entomologists, quarantine experts and other related researchers, and can provide directions to taxonomists for further taxonomic studies.
\end{abstract}

Key words: Barcoding, Biological control agent, COI, Diagnosis, Miridae, Nesidiocoris tenuis,

\section{INTRODUCTION}

DNA barcoding is a useful molecular method for identification of certain animal groups using partial DNA sequences of mitochondrial genes such as the cytochrome c oxidase subunit I (COI) gene (Hebert et al., 2004a; Hebert et al., 2004b; Ward et al., 2005; Jung et al., 2011). This method can be applied to eggs, nymph, body fragments, and morphologically cryptic groups (Hebert et al., 2003; Jung et al., 2011; Park et al., 2011). In previous studies, there have also been reports of successful COI barcoding in heteropteran species (Jung et al., 2011; Part et al., 2011; Raupach et al., 2014).

Many species of the tribe Dicyphini (Hemiptera: Cimicomorpha: Miridae: Bryocorinae) can feed on other insects as well as their host plants for survival (Gemeno et al., 2007; Namyatova et al., 2015). Amongst them, some species, such as Nesidiocoris tenuis (Reuter, 1895), also called tobacco plant bug, are well known biological control agent in agro-ecosystems in many countries. They have predatory preference feeding habits, and they can control major insect pests such as whiteflies, aphids, thrips and moths in greenhouses (Wheeler, 2000a; Wheeler, 2001; Lins Jr et al., 2014). On the other hand, these bugs also have a wide range of host plants, including certain greenhouse crops (Sanchez et al., 2008). Therefore, they are classified as insect pests, as they can

Department of Applied Biology, College of Agriculture and Life Sciences, Chungnam National University, Daejon 305-764, Korea

2 Department of Biosystems Machinery Engineering, College of Agriculture and Life Sciences, Chungnam National University, Daejeon 305-764, Korea

* Corresponding authors (E-mail: jung@cnu.ac.kr or wanghee@ cnu.ac.kr) damage crops by directly feeding on host plants such as tomato and pepper (Schuh and Slater, 1995; Wheeler, 2000b; Yasunaga, 2000; Wheeler, 2001; Arnó et al., 2009). Despite their high economic importance, their morphological identification is very difficult (Raupach et al., 2014). The aim of this study was to evaluate the effectiveness of COI barcoding as identification tool for discrimination between $N$. tenuis, which is used as a biological control agent, and its allied species, and to construct a COI barcode data of heteropterans found in a paprika farm for use in molecular diagnosis.

\section{MATERIALS AND METHODS}

Sampling focused on $N$. tenuis in Korea and Japan. In particular, Korean $N$. tenuis was separately collected from populations of natural field and paprika farms to evaluate the genetic divergences between them. Information of individuals used in this study is shown in Table 1. Most samples used in this study were directly placed in vials containing 99.9\% ethanol after capturing, to preserve the DNA. All the species were identified based on morphological characters, including the parameres and genitalia. Taxonomic references for identification are as follows: $N$. tenuis: Hernandez and Henry (2010); Cyrtopeltis miyamotoi: Yasunaga (2000); Cyrtopeltis rufobrunnea: Lee and Kerzhner (1995); Adelphocoris suturalis: Yasunaga (1990); Deraeocoris ulmi: Josifov (1983); Orius laevigatus: Jung et al., (2011); Nabis stenoferus: Kerzhner (1981); Nezara antennata: Freeman (1940).

Genomic DNA was extracted from tissues or whole body using the QIAamp DNA Mini Kit in accordance with the protocol of the manufacturer (Qiagen, Germany), after identification based on genital morphology. 
Polymerase chain reactions were performed using the Solg 2X Taq PCR Pre-mix (SolGent, Korea) with the primer pair LCO1490 and HCO2198 (Folmer et al.,
1994). The thermal cycling program consisted of an initial step of $95^{\circ} \mathrm{C} / 2$ min followed by 35 cycles of $95^{\circ} \mathrm{C} / 20 \mathrm{~s}$, $50^{\circ} \mathrm{C} / 40 \mathrm{~s}$ and $72^{\circ} \mathrm{C} / 1 \mathrm{~min}$, and then followed by a final

Table 1. Information of individuals used in this study. Population types are coded as follows: B: biological control agent; I: introduced population from natural field; N: natural species.

\begin{tabular}{|c|c|c|c|c|c|}
\hline Taxa & Location & Collecting site & $\begin{array}{l}\text { Population } \\
\text { type }\end{array}$ & Collectingdate & $\begin{array}{l}\text { Host plant } \\
\text { / Habitat type }\end{array}$ \\
\hline \multicolumn{6}{|l|}{ Miridae } \\
\hline & Korea & Daejeon & $\mathrm{N}$ & 11.viii.2014 & - \\
\hline & Korea & Daejeon & $\mathrm{N}$ & 22.viii.2014 & Humulus japonicus \\
\hline & Korea & Daejeon & $\mathrm{N}$ & 12.ix.2014 & Forbs \\
\hline & Korea & Daejeon & $\mathrm{N}$ & 5.x.2014 & Lycopersicon esculentum \\
\hline & Korea & Daejeon & $\mathrm{N}$ & 5.x.2014 & Lycopersicon esculentum \\
\hline & Korea & Daejeon & $\mathrm{N}$ & 5.x.2014 & Lycopersicon esculentum \\
\hline & Korea & Nonsan & B & 21.iii.2014 & Nicotiana tabacum \\
\hline & Korea & Hwasun & B & 16.vi.2014 & Capsicum annuиn ${ }^{\mathrm{a}}$ \\
\hline & Korea & Hwasun & $\mathrm{N}$ & 16.vi.2014 & Forbs \\
\hline & Korea & Jeju & B & 17.vi.2014 & Capsicum annuun ${ }^{\text {a }}$ \\
\hline \multirow[t]{11}{*}{ Nesidiocoris tenuis } & Korea & Jeju & B & 17.vi.2014 & Capsicum annuиn ${ }^{\mathrm{a}}$ \\
\hline & Korea & Jeju & B & 17.vi.2014 & Capsicum annuun ${ }^{\text {a }}$ \\
\hline & Korea $^{\mathrm{b}}$ & - & - & - & - \\
\hline & Japan & Tokushima & $\mathrm{N}$ & 29.vii.2014 & Sesamum indicum \\
\hline & Japan & Tokushima & $\mathrm{N}$ & 29.vii.2014 & Sesamum indicum \\
\hline & Japan & Tokushima & $\mathrm{N}$ & 29.vii.2014 & Sesamum indicum \\
\hline & Japan & Tokushima & $\mathrm{N}$ & 29.vii.2014 & Sesamum indicum \\
\hline & Japan & Tokushima & $\mathrm{N}$ & 29.vii.2014 & Sesamum indicum \\
\hline & Japan & Tokushima & $\mathrm{N}$ & 29.vii.2014 & Sesamum indicum \\
\hline & Japan $^{\text {b }}$ & - & - & - & - \\
\hline & Spain $^{\text {b }}$ & - & - & - & - \\
\hline \multirow[t]{2}{*}{ Cyrtopeltis miyamotoi } & Korea & Guemsan & $\mathrm{N}$ & 5.vi.2014 & Rosa multiflora \\
\hline & Korea & Jeju & $\mathrm{N}$ & 19.vi.2014 & Rosa multiflora \\
\hline Cyrtopeltis rufobrunnea & Korea & Hwacheon & $\mathrm{N}$ & 17.vii.2015 & Rubus phoenicolasius \\
\hline Macrolophus melanotoma & Greece $^{b}$ & - & - & - & - \\
\hline Macrolophus pygmaeus & Germany $^{\mathrm{b}}$ & - & - & - & - \\
\hline Adelphocoris suturalis & Korea & Daejeon & $\mathrm{N}$ & 11.viii.2014 & Forbs \\
\hline Deraeocoris ulmi & Korea & Daejeon & $\mathrm{N}$ & 07.x.2014 & Zelkova serrata \\
\hline \multicolumn{6}{|l|}{ Anthocoridae } \\
\hline \multirow[t]{2}{*}{ Orius laevigatus } & Korea & Hwasun & B & 16.vi.2014 & Capsicum annuun ${ }^{\mathrm{a}}$ \\
\hline & & Jeju & B & 17.vi.2014 & Capsicum annuиn ${ }^{\mathrm{a}}$ \\
\hline \multicolumn{6}{|l|}{ Nabidae } \\
\hline Nabis stenoferus & Korea & Daejeon & $\mathrm{N}$ & 15.ix.2014 & Forbs \\
\hline \multicolumn{6}{|l|}{ Pentatomidae } \\
\hline \multirow[t]{2}{*}{ Nezara antennata } & Korea & Daejeon & $\mathrm{N}$ & 27.ix.2014 & Capsicum annuun ${ }^{\mathrm{a}}$ \\
\hline & Korea & Jeju & I & 17.vi.2014 & Capsicum annuun a \\
\hline
\end{tabular}

${ }^{a}$ Full scientific name: Capsicum annuun var. angulosum

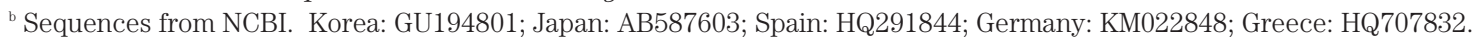


extension step of $72^{\circ} \mathrm{C} / 5 \mathrm{~min}$. The product yield was monitored by electrophoresis with $1.4 \%$ agarose gel. The amplified products were purified using a MG ${ }^{\mathrm{TM}}$ PCR SV purification kit (MGmed, Inc.), and were sequenced using an ABI PRISM 3730xl analyzer (96 capillary type) (Macrogen, Korea). All the sequences obtained were aligned with certain sequences from National Center for Biotechnology Information (NCBI) (Table 1) using Megaalign (DNA-star) and MEGA version 5.2 (Tamura et al., 2011), and were found to have no INDELs. Sequence divergences were calculated using the Kimura2-parameter model (K2P) (Kimura, 1980), and the trees were generated using the neighbor-joining method (NJ) (Saitou and Nei, 1987).

\section{RESULTS}

All the species used in this study had a distinct COI barcode sequence (480 bp). Intraspecific sequences from individuals of 4 species were identical or very similar. The average interspecific genetic distance between $N$. tenuis and its allied species (22.3\%) was 111 times higher than the average intraspecific genetic distance $(0.2 \%)$. The tree constructed based on the NJ method showed

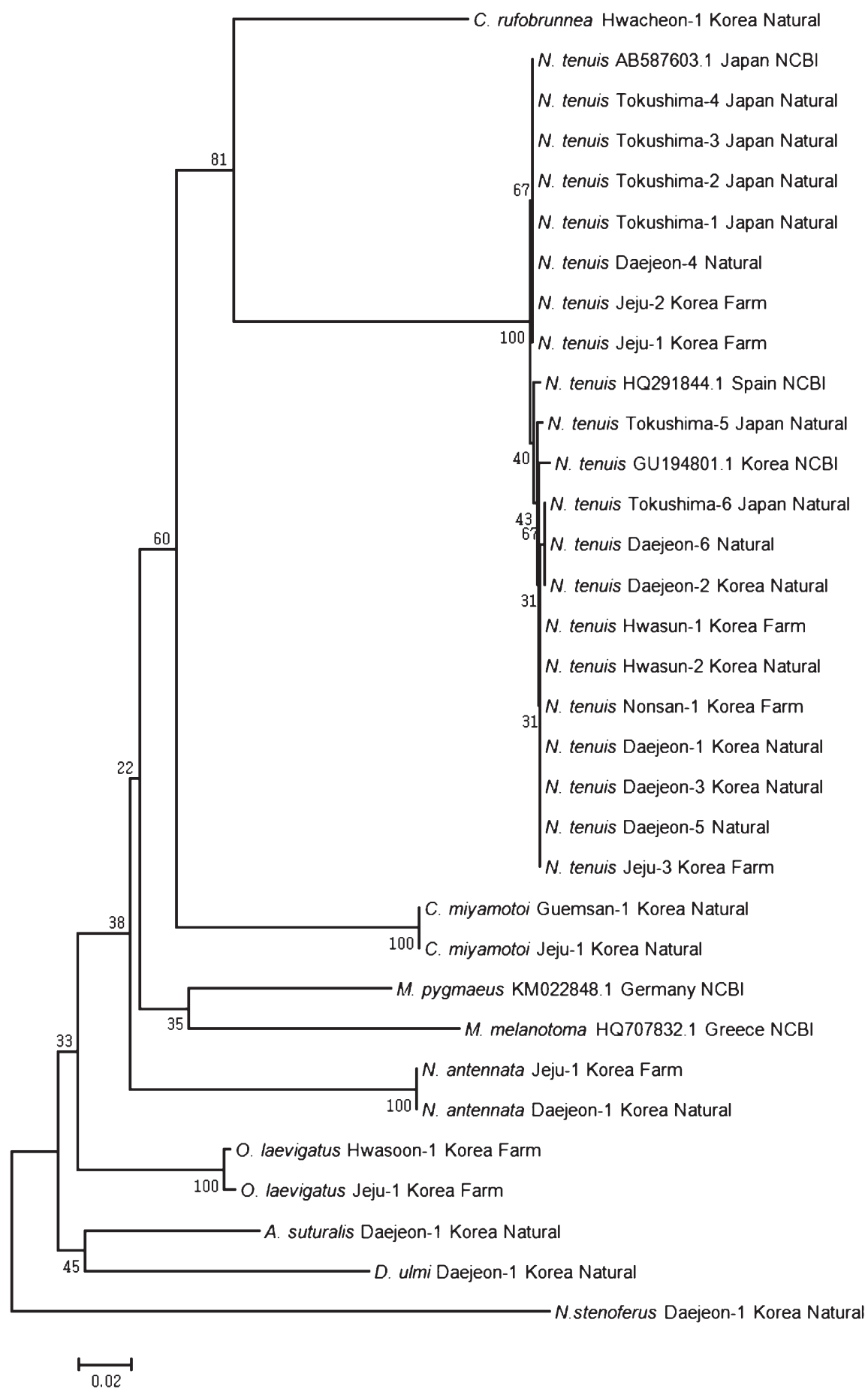

Fig. 1. Neighbor-Joining tree based on 33 COI sequences of ten species in this study. 
shallow intraspecific divergences and deep interspecific divergences.

In case of $N$. tenuis, all the individuals used in this study were clustered together regardless of the populations (Fig. 1). The average distance of $N$. tenuis (0.3\%) was lower than the average distance of Orius laevigatus $(0.6 \%)$.

The NJ tree based on COI barcode sequences was very similar to the morphological classification for most genera analyzed in this study (Fig. 1). As an exceptional, the two species of the genus Cyrtopeltis in this study were separated into two clades based on the NJ tree, indicating that $C$. rufobrunnea was clustered with $N$. tenuis in the same clade. The maximum K2P distance was $20.8 \%$, and the average K2P distance was $20.4 \%$ between C. rufobrunnea and N. tenuis.

\section{DISCUSSIONS}

To investigate the effectiveness of a COI barcode of $N$. tenuis as a molecular diagnosis tool, the levels of intraspecific variation of $N$. tenuis and interspecific distances between $N$. tenuis and its allied species were evaluated. The level of interspecific distance of all the species used in this study was found to exceed the level of intraspecific distance, and each genus consisted of distinct clades, except for the two species in the genus Cyrtopeltis. This result suggested that C. rufobrunnea was more closely related to $N$. tenuis than related to $C$. miyamotoi. To confirm their taxonomic positions, further studies would be required of additional samples of these species for morphological and molecular analysis. Furthermore, all the individuals of $N$. tenuis from different populations of natural fields and paprika farm, and Korea and Japan were clustered together (Fig. 1). This might be a result of the shorter length of the COI barcode (480 bp) used in this study, as compared to the previous barcode studies (Jung et al., 2011; Park et al., 2011).

To confirm the effectiveness of the COI barcodes, the minimum interspecific distance of congeners was compared with the maximum intraspecific distance. The average maximum intraspecific distance of $N$. tenuis and O. laevigatus was $0.8 \%$, whereas the average minimum interspecific distance of congeners was $18.5 \%$. Some previous studies on barcode for diverse animal groups have reported a minimum interspecific distance of $>2 \%$ for sister species (Klicka and Zink, 1997; Johns and Avise, 1998; Hebert et al., 2004a; Jung et al., 2011). Therefore, $N$. tenuis and its allied species can be easily distinguished using the COI barcode.

Some Dicyphini species have been used as the major biological control agents in agriculture in several countries, and they play an important role in ecosystem as predator or pests because they are zoophytophagous (Schuh and Slater, 1995; Wheeler, 2001). Among them, $N$. tenuis is one of the most popular species in many countries as a biological control agent (Wheeler, 2000; Bueno and van Lenteren, 2012). Nevertheless, this tiny bug is often difficult to identify without the help of tax- onomist. Furthermore, this species usually leads to problems for the development and maintenance of an effective quarantine system, when agricultural products and nurseries are imported and exported because of the difficulty of identification. Therefore, our results suggested that the COI barcode for $N$. tenuis and its allied species can be used as an identification tool by entomologists, quarantine experts and other related researchers, and can provide directions to taxonomist for further taxonomic studies of these species.

\section{ACKNOWLEDGEMENTS}

This study was carried out with the support of "Cooperative Research Program for Agricultural Science \& Technology Development (Project No. PJ01086106)", Rural Development Administration, Republic of Korea.

\section{REFERENCES}

Arnó, J., C. Castañé, J. Riudavets and R. Gabarra 2009 Risk of damage to tomato crops by the generalist zoophytophagous predator Nesidiocoris tenuis (Reuter) (Hemiptera: Miridae). Bull. Entomol. Res., 100: 105-115

Bueno, V. H. P. and J. C. van Lenteren 2012 Predatory bugs (Heteroptera). In "Insect bioecology and nutrition for integrated pest management", ed. by. A. R. Panizzi and J. R. P. Parra, CRC Press, Boca Raton, USA, pp. 539-569

Folmer, O., M. Black and W. Hoeh et al. 1994 DNA primers for amplification of mitochondrial cytochrome c oxidase subunit I from diverse metazoan invertebrates. Mol. Mar. Biol. Biotechnol., 3: 294-299

Freeman, P. 1940 A contribution to the study of the genus Nezara Amyot \& Serville (Hemiptera, Pentatomidae). Trans. R. Entomol. Soc. Lond., 90: 351-374

Gemeno, C., O. Alomar, J. Riudavets and C. Castañé 2007 Mating periodicity and post-mating refractory period in the zoophytophagous plant bug Macrolophus caliginosus (Heteroptera: Miridae). Eur. J. Entomol., 104: 715-720

Hebert, P. D. N., A. Cywinska, S. L. Ball and J. R. deWaard 2003 Biological identification through DNA barcodes. Proc. R. Soc. Lond. B. Biol. Sci., 270: 313-321

Hebert, P. D. N., M. Y. Stoeckle, T. S. Zemlak et al. $2004 \mathrm{a}$ Identification of birds through DNA barcodes. PLoS Biology, 2: $\mathrm{e} 312$

Hebert, P. D. N., E. H. Penton, J. M Bums et al. 2004b Ten species in one: DNA barcoding reveals cryptic species in the neotropical skipper butterfly Astraptes fulgerator. Proc. Nat. Acad. Sci. USA., 101: 14812-14817

Hernandez, L. M. and T. J. Henry 2010 The plant bugs, or Miridae (Hemiptera: Heteroptera), of Cuba. Pensoft Series Faunistica, Sofia and Moscow, No. 92, pp. 1-212

Josifov, M. 1983 Beitrag zur Taxonomie der ostpaläarktischen Deraeocoris-Arten. Reichenbachia, 21: 75-86

Johns, G. C. and J. C. Avise 1998 A comparative summary of genetic distances in the vertebrates from the mitochondrial cytochrome b gene. Mol. Biol. Evol., 15: 1481-1490

Jung, S. H., R. K. Duwal, and S. H. Lee 2011 COI barcoding of true bugs (Insecta, Heteroptera). Mol. Ecol. Resours., 11: 266-270

Jung, S. H., T. Yasunaga, and S. H. Lee 2011 Taxonomic review of the genus Orius (Heteroptera: Anthocoridae) in the Korean Peninsula. J. Asia. Pac. Entomol., 14: 64-74

Kerzhner, I. M. 1981 Bugs of the family Nabidae. -Fauna SSSR (N.S., 124). Rhynchota, 13: 1-326

Kimura, M. 1980 A simple method for estimating evolutionary rate of base substitutions through comparative studies of nucleotide sequences. J. Mol. Evol., 16: 111-120

Klicka, J. and R. M. Zink 1997 The importance of recent ice ages 
in speciation: a failed paradigm. Science, 277: 1666-1669

Lee, C. E. and I. M. Kerzhner 1995 Two new species of Dicyphini from Korea (Heteroptera: Miridae). Zoosyst. Ross., 3: 253-255

Lins, Jr J. C., J. J. A. Loon, V. H. P. Bueno, D. Barbosa, M. Dicke and J. C. Lenteren 2014 Response of the zoophytophagous predators Macrolophus pygmaeus and Nesidiocoris tenuis to volatiles of uninfested plants and to plants infested by prey or conspecifics. Biocontrol, 59: 707-718

Namyatova, A. A., F. V. Konstantinov and G. Cassis 2015 Phylogeny and systematic of the subfamily Bryocorinae based on morphology with emphasis on the tribe Dicyphini sensu Schuh, 1976. Syst. Entomol., DOI: 10.1111/syen.12140

Park, D. S., R. Foottit, E. Maw and P. D. N. Hebert 2011 Barcoding Bugs: DNA-Based Identification of the True Bugs (Insecta: Hemiptera: Heteroptera). PLOS ONE, 6: e18749

Raupach, M. J., L. Hendrich, S. M. Kuchler, F. Deister, J. Moriniere et al. 2014 Building-up of a DNA barcode library for true bugs (Insecta: Hemiptera: Heteroptera) of germany reveals taxonomic uncertainties and surprises. PLOS ONE, 9: e106940

Saitou, N. and M. Nei 1987 The neighbor-joining method: a new method for reconstructing phylogenetic trees. Mol. Biol. Evol., 4: 406-425

Sanchez, J. A., A. Lacasa, J. Arnó, C. Castañé and O. Alomar 2008 Life history parameters for Nesidiocoris tenuis (Reuter) (Het., Miridae) under different temperature regimes. J. Appl. Entomol., 133: 125-132
Schuh, R. T. and J. A. Slater 1995 True bugs of the world (Hemiptera: Heteroptera): Classification and Natural History. Cornell University Press, Ithaca and London, pp. 1-336

Tamura, K., D. Peterson, N. Peterson, G. Stecher, M. Nei and S. Kumar 2011 MEGA 5: Molecular Evolutionary Genetics Analysis using Maximum Likelihood, Evolutionary Distance, and Maximum Parsimony Methods. Mol. Biol. Evol., 28 2731-2739

Ward, R. D., T. S. Zemlak, B. H. Innes et al. 2005 Barcoding Australia's fish species. Philos. Trans. R. Soc. Lond. B. Biol. Sci., 306: $1847-1857$

Wheeler, A. G. Jr. 2000a Predacious plant bugs (Miridae). In "Heteroptera of Economic importance", ed. by C. W. Schaefer and A. R. Panizzi, CRC Press, Orlando, Florida, pp. 657-693

Wheeler, A. G. Jr. 2000b Plant bugs (Miridae) as plant pests. In "Heteroptera of Economic importance", ed. by C. W. Schaefer and A. R. Panizzi, CRC Press, Boca Raton, Florida, pp. 37-83

Wheeler, A. G. Jr. 2001 Biology of the Plant Bugs (Hemiptera: Miridae): pests, predators, opportunists. Cornell University Press, Ithaca, New York, pp. 1-507

Yasunaga, T. 1990 A revision of the genus Adelphocoris Reuter (Heteroptera, Miridae) from Japan. Part I. Jpn. J. Entomol., 58: $606-618$

Yasunaga, T. 2000 An annotated list and descriptions of new taxa of the plant bug subfamily Bryocorinae in Japan (Heteroptera: Miridae). Biogeography, 2: 93-102 